\title{
The Challenges Faced by the Refugee Children on the Immigration to Europe
}

\author{
Agil Aliyev \\ Department of Political Sciences and International Relations, Central China Normal University, Wuhan, China \\ Email: aqilalilnt@gmail.com
}

How to cite this paper: Aliyev, A. (2021). The Challenges Faced by the Refugee Children on the Immigration to Europe. Open Journal of Political Science, 11, 251-265. https://doi.org/10.4236/ojps.2021.112017

Received: January 20, 2021

Accepted: April 11, 2021

Published: April 14, 2021

Copyright (c) 2021 by author(s) and Scientific Research Publishing Inc. This work is licensed under the Creative Commons Attribution International License (CC BY 4.0).

http://creativecommons.org/licenses/by/4.0/ (c) (i) Open Access

\begin{abstract}
The XXI century is characterized by new types of wars along with new innovations. The people either perish or are obliged to move to other countries in the result of conflicts. Notwithstanding the historic movements, the most physically or morally suffering ones were children. For that purpose, the major study recorded the countries from which the refugee children came to Europe from all different places of the world, the reasons driving them out, and the conditions making Europe attractive for them. The constraints survived by refugee children, the living, health, educational and life activities faced by them were studied. The study is written by using the fields of history, social sciences, psychology, medical sciences and diplomacy.
\end{abstract}

\section{Keywords}

Refugee, Children, Problems, Europe, Diplomacy

\section{Introduction}

The international problems of the XX century reminded of two great wars were partly solved by the establishment of the UN, though this process was not fully finalized. The polarization of the world and direction of the world policy system hegemon states for their interests in the last century has become a more actual problem for our century. As said the great leader Mustafa Kamal Ataturk "to wage war to other territories with the land claim other than protecting its territorial lands is occupation but not a defense". In the result, the XXI century faced a more chaotic system. The term "terror" was added to the social-political vocabulary of the world at the beginning of the century. With this, the wars were brought to the new plane. The religious, national, racial diversity was brought to the foreground instead of being prevented and deepened the polarization. The reasons for creating chaos were wars and the result extending this situation is 
movements.

Considering the vast majority of migrants who suffered from war, socio-economic incompetence, are the inhabitants of the large African continent and neighboring eastern countries, we would be aware of the seriousness of the situation. Migrants choose Europe, which is relatively dry and connected with water part, not the other part of the ocean to facilitate migration. At this point, cultures collide. Some children were obliged to migrate alone by their parents, as well as children who have lost one or both parents as a result of the war along with the children of moving families.

The survey mainly focuses on the migration chaos in the world and the most vulnerable children in the world and the issues were encountered on the roads. Although the research on refugee children policy, problems are not mainstream and hot in the study of international politics, it also occupies a great deal of space. As the research of refugee children has strong timeliness, refugee children's studies have shown a peaking trend when refugees from various parts of the world come into being. Fruitful scholars include Emma Hadd, Rosemary Sales, G. Daniel Cohen and Benny Morris etc. The topic will involve the issue of all-around analysis of children's education theory, policy-making theory and immigration theory. The emergence of refugee children is also related to international relations as well as analyzed by international political theory.

Unfortunately, as a result of migration and refugees, the new type of problem of the XXI century, children lose this and other rights. Because 79.5 million (unhcr.org, 2019) were forced out of their lands in the world, 26 million (unhcr.org, 2019) of them are refugees and more than half of these refugees are children under the age of 18 .

The European continent is the most prominent place for refugees. European countries have been transit or stopping for these children since the 1990s. Due to numerous conflicts in the world political arena in recent years, especially conflicts occurring in the Middle East, Europe faced a migrant crisis. One-fifth of the 870,000 refugees and migrants passing through the Mediterranean Sea in 2015 were children (iom.int, 2015). Children are the most vulnerable groups of refugees and migrants. For many children, difficulties begin with migration through the sea. Each of them is endangered by violence, disease, trafficking, human rights violations and threats that end in disaster. In many cases, refugees and migrants travel on a boat and small vessels that are not provided with safety, which means that their lives are in danger. In 2015, more than 3500 people were killed in the water border of Italy and Libya, more than 30 per cent of refugees and migrants died in the Aegean Sea in 2015 were children (dailysabah.com). In May 2015, more than 1200 refugees lost their lives as a result of the sinking of the smuggler migrant ship carrying 2000 migrant refugees. In October of the same year, 90 children lost their lives in the Eastern Mediterranean Sea, most of them were between 2 - 5 years old. At the end of October, 20 children died drowning. The tragedy of the 2-year-old refugee child found dead on the shore 
once more reminded the world community about the seriousness of this problem. According to Eurostat, 802,000 refugees were registered for asylum in Europe in September-January 2015 (ec.europa.eu). Among them, the number of children was 160,000 for 2014, and 214,355 of the refugees registered for asylum in September-January 2015 were children, meanwhile, it constitutes 27 percent of those who seek asylum. The most prevalent among them are Syrian (27 percent), Afghanistan (18 percent) and Iraq (6 percent) refugee children. Refugee children from these three countries classified as Conflict Country make up 49 percent of those seeking asylum. There are children included in a special vulnerability group, disabled and children in need of special care, children temporarily parted from their parents and those moving alone among the refugee children. The babies carry a high risk of being infected with diseases depending on the changing climatic conditions during long travels. The other group is the children with psychological and physical restrictions and left for dead while travelling in Europe. The most miserable children and those whose lives a stake among these groups is homeless children finding shelter in Europe without parents or guides that were included in special vulnerability groups. In most cases, the victims of trafficking in organs and human beings are the children included in this category. 33.806 (34\%) of 100.264 children who travelled to Greece, Italy and Bulgaria in January-December of 2016 were homeless children.

\section{Child and Refugee Children in International Legislation}

"Humanity has to do its best for the child." Declaration of Geneva

Children are always in the age group who need care and special protection. They also have the same human rights as other age groups, without ethnic, geographical or religious differences. However, child rights have never been in the spotlight.

The concept of childhood emerged as a result of technological advancement and industrialization. In the industrialization, immigration environment, children were under pressure and therefore, suggested that children should be protected and defended. 1870-1920 is called the era of "the protection of children". Eglantyne Jebb, the founder of Save the Children International, has proposed the Geneva Children's Rights Declaration in 1924 for the adoption of the League of Nations. Although the document contains 5 statements, it includes the necessity of availability of child rights. This declaration also implies the existence of human rights.

From the birth, human beings have the rights and freedoms to which these rights were first adopted by the United Nations General Assembly on 10 December 1948 (Resolution 217 A of the General Assembly). Universal Declaration of Human Rights (UDHR) is a milestone in human rights history. Declaration made by representatives of different legal and cultural backgrounds from different parts of the world was declared as a common standard of success for all peoples and nations. The Declaration is the first universal international instru- 
ment adopted for the protection of human rights and translated into 500 languages. Human rights are the rights of all persons irrespective of race, sex, nationality, ethnicity, language, religion or any other status. Human rights include the right to life and liberty, freedom of slavery and torture, freedom of thought and expression, the right to work and education and so on. Everyone is the carrier of these rights, without discrimination. As stated in the first article of the Declaration, All men are born free and equal in dignity and honor. They are equipped with mind and conscience and they must act in the spirit of brotherhood. However, human rights are not always essential if they are taken into consideration in history and reality. Historically, slavery, social stratification is still the case in many countries around the world, despite the $21^{\text {st }}$ century. Although war, conflicts are between the states and groups, their results are directly aggression against human rights and freedoms. If assessed from a legal aspect, the article of UDHR "Everyone has the right to life, liberty and security of person" is deemed to be violated. As the protection of rights relates to the whole humanity, mankind, article 25, item 2 of the declaration provides a special place for children "Motherhood and childhood are entitled to special care and assistance. All children, whether born in or out of wedlock, shall enjoy the same social protection." This item connected with the children delivers to the attention that they are a special age group.

The post-II World War situation became a new stage in the approach to children. The UN General Assembly declared Declaration of the Rights of the Child on November 20, 1959, with the 1386 (XIV) resolution. The Declaration states that the United Nations Organizations approves the belief on fundamental human rights and human values, irrespective racial, color, sexual, language, religious, political and other thoughts, national or social origin, status, everybody has the rights and freedoms declared by the Universal Declaration of Human Rights, child, because of his physical and mental immaturity, needs special safeguards and care, including appropriate legal protection, before as well as after birth. The Declaration consists of 10 articles and implies that each child has the right to "happy childhood". Conventionally, the Convention on the Rights of the Child was adopted by the resolution $44 / 25$ of the UN on the 30th anniversary of Child Rights Declaration, on the 10th anniversary of the International Child Year in the $44^{\text {th }}$ UN session on November 20, 1989. The Convention was compiled based on the declaration adopted on child rights and is more comprehensive. CRC is the most comprehensive and child-friendly international document describing the political, civil, social and economic rights of children. The Convention does not only protect children's rights and freedoms against threats and exploitation but also protects the rights of childhood, its formation as an independent person taking care of them as an individual with a voting right and is composed of three sections and 54 items that cover comprehensive child rights. One of the most popular children's right typologies discusses four categories or principles from the CRC: non-discrimination; the best interests of the child; the 
right to life, survival and development; and participation rights. Although the Convention was adopted in 1989, it also covers the manifestation of subsequent violations of child rights. Therefore, the Convention is a unique means of protecting children's rights.

In the post-II World War situation, the cases of violation of the child rights are of the same nature with the war actual for the world reality and the children whose rights were violated in this result. The feature making it specific for the $21^{\text {st }}$ century for the children killed during the war lost parents and subjected to grave conditions as migration is their being from other regions of the world not from Europe. Article 22 of the Convention protecting the children irrespective of religion, language, race, the geographic region is connected with the refugee children being an actual problem of the $21^{\text {st }}$ century.

\section{Push Factors for the Refugee Children}

European Union countries have never been the source of hope for refugees, which have always been as relevant as ever. From the late 18th to the middle of the 20th century, Europe was not a place of immigration, but rather a place to emigrate.

In the late $19^{\text {th }}$ and early $20^{\text {th }}$ century, the United States and other states took note of the need to take measures to regulate the migration problem. Europe faced the first refugee crisis after the I World War and the 1917 Russian Revolution. 30 million in the first 4 years of the II World War and more than 40 million refugees after the war ended in 1945 led to the second refugee crisis. After the collapse of the Berlin Wall, the collapse of the USSR and the war in Yugoslavia, European countries again faced the flow of refugees and internally displaced persons. The third crisis in Europe coincides with the time when the United States and its ally western bloc were in Afghanistan and Iraq after the 9/11 attacks in the early years of the $21^{\text {st }}$ century. At present, the world is witnessing an unprecedented refugee crisis and the European continent is the center of the fourth largest refugee crises in history having difficulty in solving.

The biggest contributor to the refugee crisis in Europe is Syria. Syria was able to provide its citizens even before March 2011, though was a low-income country before the conflict began. Syria was also considered to be a state inhabited by various faiths and ethnic minorities throughout the centuries, living in the history of Arab and eastern culture. However, the Arab Spring, which began in the eastern part, could not go beyond Syria. According to a study by the Syrian Political Center in 2016, more than 470,000 people have been killed since the onset of the conflict, of which over 12,000 were children. Impact of lack of living conditions on children was worsening the situation. The investigation of UNICEF indicates that nearly 7 million children are obliged to live under low living conditions in Syria. According to analyses 2015 of the Food and Agriculture Organization and the World Food Program, 9.8 million Syrians suffer from food security. The Syrian children also subjected to torture and sexual violence. UNICEF 
announced that 1500 acts were drawn upon the violence of children's rights and $60 \%$ of them have resulted in their death in 2015, also UNICEF estimates that 8.4 million children suffer as a result of congestion in Syria. 6 million Syrian children required humanitarian aid and more than 2 million children were in hardly accessible places for the assistance.

Iraq is the war firing ground of the Middle East turned to the place of war that was not ended by the overthrow of Saddam Hussain in 2003. During 2003-2013, over 4 million Iraqis have displaced that more than 2 million of them is children. Every year, 35,000 babies die without reaching to 1 year, more than 1.5 million children are under 5 years old, 2.5 million children lack fresh water. Multiple people are killed in Iraq every day in the result of terror acts and $8.1 \%$ of them is children. According to the UN Development Program, millions of children have been the victims of conflicts and terror acts since 1991.

Afghan refugees also leave the country because of the war and internal conflicts continuing from 1978. The destructive traces of arrival of USSR military forces to Afghanistan in 1978 and coming to power of the radical Islamic patriots n 1992 remain in the history of Afghanistan. Many people were killed during the war. They went mostly to Pakistan and Iran in the early years of the war and conflict. The war began by the US and coalition forces in 2001 created the second Afghan refugee stream. Social and political difficulties continue in the country. The civil war in the country's domestic religious space, in the years 2001-2016, killed 111,442 Afghans as a result of the Taliban's war against the US and its coalition, but the number of children killed during military operations by the US and coalition forces is unknown. The UN estimates more than 300,000 children became disabled as the victims of conflict in the Soviet-Afghan war and war between the Taliban, the US and Coalition.

The poverty rate in Afghanistan is $46 \%$ and it is nearly half of the population. Afghanistan is the second poor country in the world. 35\% of newborn babies are below normal weight. $87 \%$ of children are born at home without any medical condition. As other refugee children, the Afghan children are also victims of sexual maltreatment and violence. Thousands of children under 18 age are forced to become the soldiers of the Taliban or other terrorist groups under the Taliban regime. As well, child rights are also violated by such cases as forced marriage before 18 years old. It was revealed from the survey carried out in 2000-2009 that $40 \%$ of young women were married before 18 years old. The age of the young refugees from Afghanistan ranges between $15-24$.

Differing from other refugees, the reasons for the migration of the refugees from Africa are local conflicts and cruelty of the political regime, however, unlike the refugees of the Middle East, the forced migrants of the African continent for various reasons migrate to neighboring countries instead of Europe. One of the political disturbances suffer by the Eritreans, likewise, the miserable conditions created by the political regime was included Eritrea in the list of 12 "worst of the worst" countries according to the report of Freedom House 2015. South 
Sudanese $614,135(61 \%)$ of $1,006,779$ refugees were children where instability of political governance is continuing.

According to UNICEF's estimates of 31 August 2017, 22,602 (59\%) of 382,322 refugees in Ethiopia and 71,221 (66\%) of 107,902 South Sudanese refugees in Kenya are children. $82 \%$ of 1 million refugees in Uganda, one of the countries that have adopted South Sudanese refugees, were women and children. Only 515 of southern Sudan refugees have sought asylum in Europe during 2012-2016. Another country of Africa surviving refugee crises is Eritrea. Eritrean refugees, like many other African refugees, have settled in Ethiopia and Sudan in their continent. In 2015, about 17,810 refugees found asylum in Europe and $90 \%$ of them are at the age of $18-24$.

\section{Challenges on the Roads to Europe: Mediterranian Basin}

The Mediterranean Sea being the only border separating Europe from Africa from both geographical and cultural point of view is one of the centers of human civilization. Cultural, commercial relations have been transported from Europe to Africa, from Asia to Europe through this sea. But, the Mediterranean Sea is mainly one of the transition centers of the human migrations for our century.

The photo was taken by a Turkish journalist Nilufer Demir of three years old Syrian refugee of Kurdish origin Aylan Kurdi whose dead body was found by a Turkish policeman on Bodrum coast, Turkey of the Mediterranean Sea on 2 September 2015, directed the attention of the world community to the problem of refugees and juvenile victims of this problem. The found body proves that the sea is not the only place of resort of the people in the summer, but also it is a cemetery for many people, more precisely, for the refugee children. The Turkish policeman Mehmet Chiplak was the first to see the dead body of Alan. Nilufer Demir employed at "Dogan News Agency" says: "I could do nothing but to take her photo. I thought that it is the only way to convey the shout of this silent corpse." It is enough to imagine for a while yourself or your child on small boats carrying hundreds of refugees to understand the tragedy in the Mediterranean Sea of the refugee crisis. This crisis has deeper and more tragic meaning with the words of the children attending hard sea trips. The only way to Europe for the refugees from Africa and Palestine is the Mediterranean Sea. According to the information given by UNHCR, refugees passing to Europe through the Mediterranean Sea were from Syria $(18,171)$ from the Middle East, from Nigeria $(18,401)$, Guinea $(13,847)$, Cote d'Ivoire (13,488), Morocco (11,626), Gambia (8650), Algeria (8486), Eritrea (8236), Mali (7860) from the African continent, from Bangladesh (9036) from Asia from 2017 up to the present time. The Mediterranean Sea becomes the opportunity presented by the fate of some people and the last destination for others. According to the statistics provided by UNHRC, the number of the survivors passing the Mediterranean was 216,054 in 2014, $1,015,078$ in 2015, 362,753 in 2016, 172,301 in 2017 and 7865 in 2018. The number of dead and missing persons in the Mediterranean was 3538 in 2014, 3771 in 
2015, 5096 in 2016, 3119 in 2017 and 368 in 2018. 18.4\% of the refugees passing through the Mediterranean Sea since 2017 have been children. More than 100,000 children using this passage in 2016 were under 18 years old. According to the information given by UNICEF, more than 700 persons out of 4579 persons died in the maritime border between Libya and Italy were children. More than 150 children from North Africa died in the central Mediterranean basin in the first quarter of 2017. 3020 refugee children survived to Greece, 12,239 refugee children survived to Italy and 995 refugee children survived to Spain.

Life tragedy in the Mediterranean Sea expressed with the words of 7 years old Malak, a Syrian refugee: "It was very big. When I first saw it, I was afraid. But when I got on the boat I liked it. I was not afraid anymore. Once it moved, water started getting into the boat. And we got sprayed by the water. It felt as if my mother and I might drown. That the boat might go down. When we moved a little, the water splashed on us. It was very cold. After I got cold, I was very scared. We had a bag with our clothes. I told my mother I want to wear my clothes. But someone threw our bag away when we got on the boat. When the sun rose the fuel ran out and a fisherman with his boat pulled us to shore. Once we got to the shore, we tore the rubber boat, threw the life vests away and moved on to the mountains. The mountain was very high. Every time we reached a peak, I thought it was over, but we continued to go higher. Bur, I swear I do not remember where we slept, I forgot. After we got to the road, we cleaned ourselves from the dust and went to the police. After we finished with the police, they told us to go. I miss my school in Syria and I miss my teacher. I had a lot of friends. Now there is no one left. I hope things get back to how they were. I hope Syria gets back to how it was" (unicefusa.org).

19 years old Doaa, who passed through tortures and managed to reach Europe, but first of all moved to Egypt and her beloved man, other Syrian refugee hoping to have a comfortable life in Europe, Bassem. Life was very difficult for Doaa in Egypt. She could escape on the brink of sexual violence for sometimes. Two Syrian young refugees got married and then migrated to Europe through the Mediterranean Sea on a boat where more than 500 refugees were placed against a certain amount of money. The boat where young and elder Christians and Muslims were placed was perforated and most of the refugees had to jump into the water. Like other refugees, Bassem and Doaa were helpless without life jackets in the sea. Husband of Doaa, Bassem lost his life in the sea. Doaa struggled for life in the water with some children given to her by other refugees. As two of the children given to Doaa died, she had to leave them to the water. Doaa was rescued with two children on the fourth day of hung and thirsty struggle in the sea. But, one of the children lost his life too. Only 11 refugees out of more than 500 refugees survived.

According to the study of IOM, 3280 children and juveniles lost their lives in 2014, 3772 in 2015, 2977 in 2016. Children who lost their lives or who reached Europe accompanied by tortures are not limited to the Mediterranean Sea. They 
face different pressures and difficulties on land too.

\section{Challenges on the Roads to Europe: Arid Roads}

The migration of refugees to Europe is directly (sea) or by indirect means (road). In both cases, it is impossible to avoid danger. The European desire for refugees from Eritrea, one of the African countries, comes from Sudan, Libya and other countries. Somalia's refugees move to Europe through Ethiopia, Sudan and Libya. Refugees from the Middle East are more likely to be the refugees travelling through Turkey and Macedonia to the European stage in Greece. The Afghan refugees cross the border between Turkey and Iran, where Syrian refugees are forced to choose. The most victims of deprivation, difficulties and deaths on the roads are refugee children. They were forced to continue their migrations in the cold winter, at the heat of the summer, at different times of the year, not exactly in the season. The poet of the Somali-born English poet, Warsaw Shiren, says, "No one puts their children in a boat unless the water is safer than the land" The land used by the refugees from the current refugee situation to the European stage is the Republic of Turkey. Even Turkey is the world's number one country for several refugees. The Turkish government has registered 3,485,644 refugees, the majority of which are from Syria, Iraq, Afghanistan, Iran and Somalia. The number of Syrian refugees is rather more. Geographically, it is more convenient to move to Turkey, which is situated in the north of Syria. Turkey is a comfortable country for refugee and refugee children's temporary asylum or immigration to Europe, from a religious and cultural aspect. Actions aimed at stabilizing the situation in the region and mediating in the creation of peace are a safe place for refugees. Refugee flow from Syria to Turkey began with the refuge of 250 - 300 Syrian refugees' refuge to the country in 2011. Based on the cancellation of visa regulations between the Syrian state and Turkey in 2009, the "Open Door" policy is pursued, Syrian refugees. But, the refugees who found shelters in the territory of Turkey from Syria or other regions or staying in Turkey temporarily have joined to the Geneva protocol 1967 of Turkey with "geographic limitations" and it grants the status of refugee to those coming from European countries and seeking shelter by being prosecuted for their racial, religious, nationality, ethnic origin and political views based on the document. According to this document, the Syrian or other refugees are considered to be "guests" in the territory of Turkey. The absence of any legal basis of the status of "guest" in international laws forces the refugees in Turkey to leave for Europe. While $9 \%$ of 3,485,644 refugees founding shelter in Turkey live in refugee camps, the other part, $91 \%$ live outside the camps, in cities and settlements. 53\% of the refugees are the children under 18 years old, more than $75 \%$ are the women and children in need of special care. While the number of Syrian refugee children in the age of $0-4$ is 515,116 persons, this number is 447,632 persons according to the statistics as of 25 January 2018. But the difficulties connected with the refugee children exist here too. Their settlement outside the camp puts 
their life on the threat. The difficulties faced by refugee children in Turkey are security and education. Early marriage of girls is also widespread in Syria. Although families consider this step to be a safeguard for girls, these lead to serious physical and psychological problems in children, in particular, refugee children. It is another problem for refugee children to be deprived of these rights when considering education as one of the basic foundations of the nation and the state. The level of education of the Syrian population before the war is high. $76.9 \%$ of the portion of the population above 10 years old has reading and writing abilities. Although $80 \%$ of children living in refugee camps in Turkey can benefit from the right to education, $14 \%$ of refugee children outside the camp cannot benefit from this opportunity. Thus, $86 \%$ of refugee children residing outside refugee camps are deprived of this right. From the tongue of the 16-year old Syrian refugee staying in Turkey as a guest: "I am 16 years old and I go to school. When the war started, our home, school and everything turned to ruins. I hope that I and my friends here will be engineers after finishing school and we will rebuild our country" (unicef.org). Though Turkey is a convenient place for refugees to live in, they're being considered to be guest is one of the main reasons why they are immigrating to Europe. Refugees can reach the border only via Bulgaria and Greece through the Aegean Sea. Harmanli refugee camp located 60 $\mathrm{km}$ south of Bulgaria is their initial settlement in Europe. However, most refugees do not want to seek refuge in Bulgaria because they are connecting their ideal European life with Germany. In the first quarter of 2017, there were 270 refugee children in Bulgaria, most of whom are from Syria and Afghanistan. The fact that most refugees are families with many children makes it difficult for children and families to work. The living conditions of refugee children in Greece are much worse than in Turkey. Living conditions in the Moria refugee camp, surrounded by woods surrounding the island of Lesbos, Greece, where refugees, including children, are embraced, are experiencing the same emotional tension, although they are far from home. Moria refugee camp is one of the worst camps in the world. Location in the mountainous area and the absence of sanitary junctions makes the refugee camp risky for life. According to the UN Refugee Agency (UNHCR), the Moria Camp was intended to accommodate 2000 refugees, but the number of refugee of the camp exceeds 6000. This increases the risk of danger of the camp for refugee children. Winter is the true hell for refugees. The number of refugees in Greece is 62,000, more than half of which are women and children. 12,000 children in Greece go to school (6 - 17 years). When the problem is assessed from an educational perspective, it is a well-known fact that refugees who are educated or not, spend their time in vain and this leads to complications in the social life of their future countries.

In Moria's refugee camp, children were also deprived of the right to education. From the tongue of Ely Qias, a 16-year-old refugee from Afghanistan; " $I$ wanted to study after reaching Europe" the 16-year-old Ely Qias, who together with his mother and seven sisters came from Iran to Turkey because of the war 
in Afghanistan's Helmand Province, placed in the Moria refugee camp in Lesbos and the education and other wishes of the refugee children are destroyed in the unfavorable conditions of road and camps.

\section{Refugee Children Whose Rights Are Violated before Reaching Europe}

After leaving their homelands the refugees think that they have escaped from the war and its disturbances, low living conditions caused by the cruelty of the regime. But salvation is not ended by fleeing from the country. They escape from the problems available in their country and find themselves inside other problems. Children are subjected to the worst sides and complications of the problem. Besides violation of the rights of the refugee children in their countries, they face with such problems as lack of normal living conditions both on their way to Europe and in the refugee camps, sexual abuse and child labor. Refugee children have to continue living with the traumas on one hand of the war and disasters of the country where they escaped from and on the other hand of the tortures or difficulties faced during migration. In most cases, they commit suicides because of psychological tension and stress caused by such kind of traumas. Consequently, a part of the refugee children is characterized as a lost generation.

According to the 1989 Declaration on the Rights of the Child, the rights of the refugee children are not violated only by the disturbances caused by war, but also by the hardships faced during migration. The rights of the refugee children stipulated in Article 24 "Health and using health services", Article 26 "Social Security", Article 27 "Enough living standards", Article 28 "Education", Article 31 "Recreation, evaluating leisure time and attending cultural events", Article 32 "Laws on child labor", Article 33 "Protection against the use of drugs", Article 34 "Protection against sexual abuse", Article 35 "Protection against being sold, abduction and prostitution", Article 36 "Protection against other types of abuse", Article 37 "Protection against torture and deprivation of liberty" and Article 38 "Protection against armed conflict" of the Declaration are seriously violated and the refugee children cannot use the international rights that they are entitled to. In 2016 only 851 armed children used in the conflicts, 652 killed children and 647 disabled children (including refugees too) were registered in Syria.

Girls abducted and forced into marry, arrested and subjected to sexual violence by groups or persons are another shaded face of the problem. It worries that not only girls but boys are also victims of sexual violence. Tarek from Syria says: "When I was imprisoned in Syria I was tortured by all possible means. 80 persons stayed in one cell without electricity for 30 days. All of us were nude and every night we were handcuffed and tortured by electric shock. They came to the cell only to torture us" (unhcr.org, 2017). The youngest tortured man was 10 years old and the oldest man was 80 years old. The refugee children are subjected to sexual violence not only in their countries but also in the migration ways and refugee camps by other elder refugees. Nearly 30 refugee children of 8 
- 12 years old were victims of the sexual violence by Turkish soldiers in Nizip refugee camp located $50 \mathrm{~km}$ away from Syria-Turkey boundary. The violence was committed by the servicemen employed in the camp (sandiegouniontribune.com). Most of the refugee women living in another country of the Middle East in Libya have to render escort services at the hotels and brothels to ensure their living. Mostly, refugee children not accompanied by anyone or who lost their family members become the victims of human traffickers and tools of sexual abuse. Being the "corridor of incubus" of the refugee children and other refugees going to Europe, the Mediterranean Sea is also another center of the sexual violence for the African refugees. Women and refugee children (mainly girls) are victims of sexual abuse of human traffickers. Refugee women, children who cannot give money for migrating to Europe are forced to sexual violence by human traffickers against services rendered by them.

Child labor or forced child labor is another problem of refugee children. 85\% of the Syrians live under conditions below poverty. Children constitute $75 \%$ of the workers. They are obliged to work alone or together with their family members to provide their families. Children are employed almost in all fields of the service sector. Beggary is also widely spread among children. 4 years old Syrian refugee living in Lebanon Fares says: "I can neither write nor read, but I can draw the picture of the sky, the sea and the sun. I worked as a cleaner at the restaurants and cafes. I want to leave my house because it is like a prison."

Refugee children have to work in the countries where they immigrate to as normal living conditions are not provided for them and they have to help their families to live. Child labor and child workers are illegal in most of the countries. In most cases, refugee children are employed by local entrepreneurs. Because they pay very little money for their work and they don't pay taxes for them. Child labor and child workers are illegal in Turkey too. But 11 years old refugee girl Aras migrated to Turkey works for 12 hours at a tailor's shop in Istanbul. Aras says: "I would like to go to school, but it is not possible. We pay the rental fee. Food, water costs are very expensive. Therefore, I have to work and help my family." Another reason for a threat to the refugee children is that they are not insured against any hazard or accident at illegal workplaces. Another tragic consequence caused by wars and conflicts is the appearance of people profiting from confusion, human traffickers and body mafia. Services of mafias are wide both in their homelands and in the migrated countries. You shall pay money or offer your kidney instead of money or sell your child if you want to go to Europe. The biggest victims of the mafia are refugee children. ISIS is another group taking income from this commerce. A Syrian woman called Nadia Kamal, a resident of al-Qadam dwelling area near Damascus whose child was abducted says: "My 8 years old daughter Raghad disappeared while playing in the park. When I could not find her at the hospitals, I placed an announcement about her disappearance, but she was not found. Ten days later a person whose identity was unknown called me and said that my daughter was well and after having taken over 
my daughter, I saw traces of operation on her body. After the examination of the doctor, it was known that one of her kidneys had been taken."

Captivating women by ISIS and selling them to human traffickers against 20 thousand dollars has become the source of income of the terrorist group. The fearful situation is related to refugee children. Unfortunately, sometimes local doctors abduct children or break the lives of the refugee children who take refuge in their help. It was reported in surprising research published in Haaretz newspaper in the $4^{\text {th }}$ year of war in Syria, in 2015, that Syrian Association of Doctors had taken the license from 5 Syrian doctors as they had been engaged in organ trafficking. Many doctors in Syria shall survive the war conditions honestly. Another tragic aspect of the chaos is that human trafficking, more precisely, child trafficking is conducted before their birth. Pregnant Syrian women are taken to Lebanon for delivery and immediately after the delivery, newborn infants are either sold to families who want children or their organs are taken and offered to buyers. In some cases, organ mafias and refugees themselves don't even hesitate to place an announcement that they sell their organs on the social networks. The reason is to go to Europe and to provide their daily needs (haaretz.com). It was declared by the General Director of UN Syria Coroner, Dr. Hussein Noufel that organs of 18,000 Syrian refugees including refugee children had been taken and sold on the black market since the beginning of the war in Syria and up to 2017. A kidney is sold for 10,000 dollars in Turkey, for 1000 dollars in Iraq, for 3000 dollars in Lebanon. Another source of income for earning money and proving the life of the family is the sale of refugee children and organs.

Not only entrepreneurs take benefit from the services of the refugee children, but there are also persons more dangerous than they. They are refugee children abducted or bought from human traffickers against a certain amount by terrorist groups and military unions. These cases mainly exist at ISIS-controlled parts of Syria. Children whose schools and children have been ruined have to go to "schools" established by ISIS. Instead of worldwide education, the children are taught "sharia lessons" and firing rules. Hamid who escaped from control of ISIS to Jadah refugee camp in Iraq says: "They teach children how to make primitive bombs and to be like them. They punish in different methods the children who do not go to schools established by ISIS and who do not obey their rules. When children came back from there, we explained to them that the words of ISIS were false and concocted." Terrorist groups use the children's services mostly as kamikaze. Absences of conditions for education, abducted or homeless children are also potential terrorists for Europe during migration. Homeless refugee children in Europe or other migrated places or provocation by other elder refugees makes them a potential source of danger.

The sorrowful point is that besides destructing lives and hopes of the refugee children, the rest of their lives is either ended as the victims of sexual abuse or military unions or they are integrated into a new world as individuals with psy- 
chological trauma. Refugee children witnessing the violence of the war in their childhood, refugees obliged to sell their kidneys and become the tool of aggression will demonstrate individuals with a new character when they grow up. Improvement of their present conditions, positively directing their future lives and growing up individuals useful for the society depends on the laws and the indigenous population of the country where they migrate to.

\section{Conclusion}

Europe still is hope for refugees especially refugee children who obliged to flee their homeland with or without parents. Human disasters, problems keep their urgency during their journey to Europe. As long as wars, conflicts extend, forced migrations also continue. Unfortunately, the basic principles of human rights, also accepted regulations by the International Organizations for the protection of refugee children are not applied. In this circumstances, refugee's hopes smugglers and human traffickers are doing their job with increasing numbers of immigrants and who cannot succeed in their journey to Europe, either die in the seas or become victims of torture and organ trafficking on the roads. On the other hand, the European community endeavors its best assistance to provide necessities for whom already in the EU borders. Nevertheless, the international organizations, particularly the UN and International Organization for Migration take action in maintaining refugee children's rights.

\section{Acknowledgements}

I express my deep gratitude for the professors of the Department of Political Sciences and International Relations of the Central China Normal University, especially professor Mr. Zhao Chanfeng for his encouragement and modesty for moral and ideological contributions for this research.

\section{Conflicts of Interest}

The author declares no conflicts of interest regarding the publication of this paper.

\section{References}

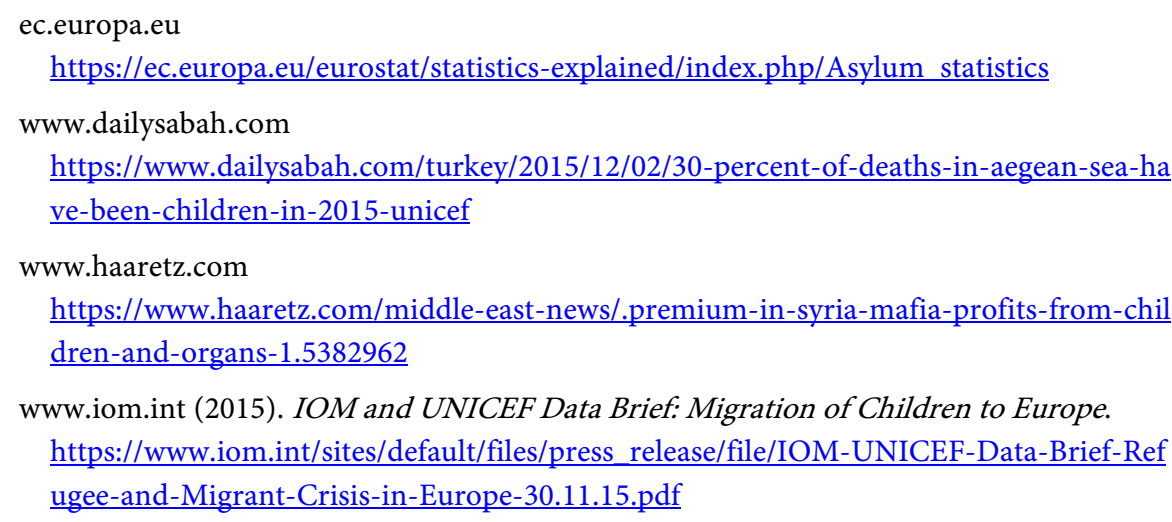


www.sandiegouniontribune.com

http://www.sandiegouniontribune.com/hoy-san-diego/sdhoy-30-syrian-children-suffer -sexual-abuse-rape-in-2016m\%20ay12-story.html

www.unhcr.org (2017).

http://www.unhcr.org/news/press/2017/12/5a27a6594/unhcr-study-uncovers-shocking -sexual-violence-against-syrian-refugee-boys.html

www.unhcr.org (2019).

https://www.unhcr.org/globaltrends2019/

www.unicef.org

https://www.unicef.org/turkey/en/reports/children-syria-turkey-info-sheet-july-2016

www.unicefusa.org

https://www.unicefusa.org/stories/malak-and-boat-\%E2\%80\%94-one-syrian-childs-jou $\underline{\text { rney/30179 }}$ 